\title{
シリコーンゲルで封止されたワイヤの振動環境下の疲労強度評価法
}

\author{
竹 田 憲 生* 成 瀬 友 博* \\ 河 野 賢 哉** 服 部 敏 雄*
}

\section{Fatigue Strength Estimation Method of Wire Protected with Silicone Gel under Vibration Environment}

\author{
by \\ Norio TAKEda ${ }^{*}$, Tomohiro NARUSE ${ }^{*}$, Kenya Kawano ${ }^{* *}$ and Toshio Hattori ${ }^{*}$
}

\begin{abstract}
Silicone gel is usually applied to electrical automotive devices to protect them from corrosion. However, under a vibration environment, the silicone gel vibrates bonding wires in the devices; thus, to evaluate the reliability of the devices, the vibration analysis of the gel/wire structure is indispensable. In this study, we clarify the relation between the fatigue life of gel-protected bonding wires and the geometry of the gel and bonding wires experimentally. It was founded that the diameter of wires and the thickness of the gel have a significant influence on fatigue life. Then, we developed a method, based on a vibration analysis model that takes into account the visco-elasticity of a gel, for predicting the fatigue life of the wires. It was confirmed that the predicted fatigue life showed good agreement with the measured fatigue life. Finally, we developed a design tool for easily calculating the fatigue life of the wires. This tool estimates the strain range by using a response surface, i.e., a neural network. As Bayesian regularization was executed in learning of unknown parameters in the neural network, we could make the response surface and ensure good generalization ability.
\end{abstract}

Key words : Silicone gel, Vibration, Electrical device, Bonding wire, Fatigue life

\section{1 緒言}

近年, 自動車用電子部品は配線作業の工数低減を四る ため, エンジンルーム内に設置あるいはエンジンに直付 けされる傾向にある。午のため, 自動車用電子部品はよ り過酷な熱扔よび振動環境下で使用され，これらの環境 に対する信頼性確保が重要な課題となっている。自動車 用電子部品では, プリント基板上の配線やボンディング ワイヤを水滴などから保護するため, プリント基板全体 をシリコーンゲルで封止しているものが多い．このシリ コーンゲルの特性選択を誤ると, 過酷な振動環境下でシ リコーンゲルがボンディングワイヤを加振し， ワイヤを 疲労断線させることがある。このような疲労によるワイ ヤの断線を防ぐためには, ゲル封止されたワイヤの振動 挙動を明らかにし, ワイヤの強度評価を行う必要がある。 そこで, 著者らは先にレーザドップラ振動計でゲル中の ワイヤの振動を測定し，ワイヤがゲルとともに振動する ことを明らかにした．また，ゲルの粘弾性を考慮したゲ ルとワイヤの連成振動解析法により, ゲル中のワイヤの 振動挙動が計算できることを確認した。

本報では, ゲル封止されたワイヤの振動環境下での強 度評価法について検討する。.まず，ゲルで封止されたワ イヤの振動環境下での疲労試験を実施し, 様々なゲル, ワイヤの寸法, 加振条件でワイヤの疲労寿命を明らかに する. 次に, ゲルとワイヤの連成振動解析で計算したワ
イヤのひずみ範囲とワイヤ単体の疲労試験結果から，ゲ ル封止されたワイヤの疲労寿命を予測する手法を提案す る. 最後に, 設計者が基本構造設計段階でワイヤおよび ゲルの寸法変更による疲労寿命の変化を簡便に概算でき るゲル封止ワイヤの簡易寿命評価法を提案する。

\section{2 ゲル封止ワイヤの振動環境下疲労試験 \\ $2 \cdot 1$ 試験方法}

アルミワイヤをシリコーンゲルで封止した Fig. 1 (a)の 試験片を作製した，ゲルの底面は絶縁被膜を挟んでアル ミの板に付着しており，ゲルの側面は拘束されていない． ワイヤは銅配線上にボンディングし，銅配線にリード線 を接続してワイヤに通電できるようにした。ワイヤおよ びゲルの寸法が異なる Table I の 4 種類の試験片をそれ ぞれ数個ずつ用意し, 加振器で試験片に振動を与えてワ イヤを断線させた. Table Iの $l, w, h$ は Fig. 1 (a)に示 したゲルの寸法である. 試験片の加振方向を Fig. 1 (a)の $y$ 方向とするため, Fig. 1 (b)のように治具を介して試験 片を加振器に取り付けた。加振周波数は $60 \mathrm{~Hz}$ に固定し， 加振加速度を変化させて試験片を加振した. 加振時にワ イヤに通電しておき, 電気信号の変化でワイヤの断線を 確認した。ワイヤが断線するまでの時間を記録し，断線 時間と加振周波数からワイヤの破断繰返し数を求めた.

\section{$2 \cdot 2$ 試験結果}

試験結果を Fig. 2 に示す. Table I に示した試験片 1 
Table I . Geometry of wire and silicone gel.

\begin{tabular}{c|c|c|c|c}
\hline & \begin{tabular}{c} 
Silicone gel \\
\cline { 2 - 5 }
\end{tabular} $\begin{array}{c}l \times w \times h \\
(\mathrm{~mm})\end{array}$ & $\begin{array}{c}\text { Span } \\
(\mathrm{mm})\end{array}$ & $\begin{array}{c}\text { Height } \\
(\mathrm{mm})\end{array}$ & $\begin{array}{c}\text { Diameter } \\
(\mathrm{mm})\end{array}$ \\
\hline 1 & $30 \times 30 \times 8$ & 11.0 & 5.0 & 0.125 \\
\hline 2 & $30 \times 30 \times 8$ & 11.0 & 3.0 & 0.125 \\
\hline 3 & $30 \times 30 \times 8$ & 11.0 & 3.0 & 0.200 \\
\hline 4 & $30 \times 30 \times 2$ & 11.0 & 3.0 & 0.125 \\
\hline
\end{tabular}

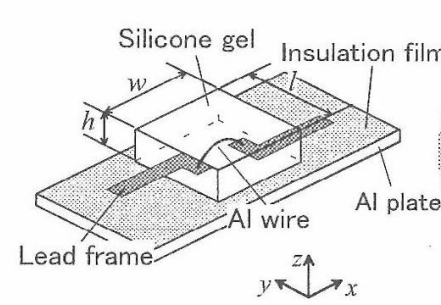

(a) Specimen

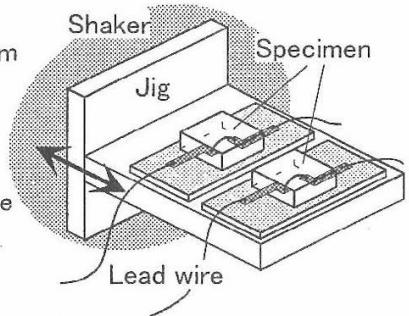

(b) Setting of specimen
Fig. 1. Specimen and setting of specimen.

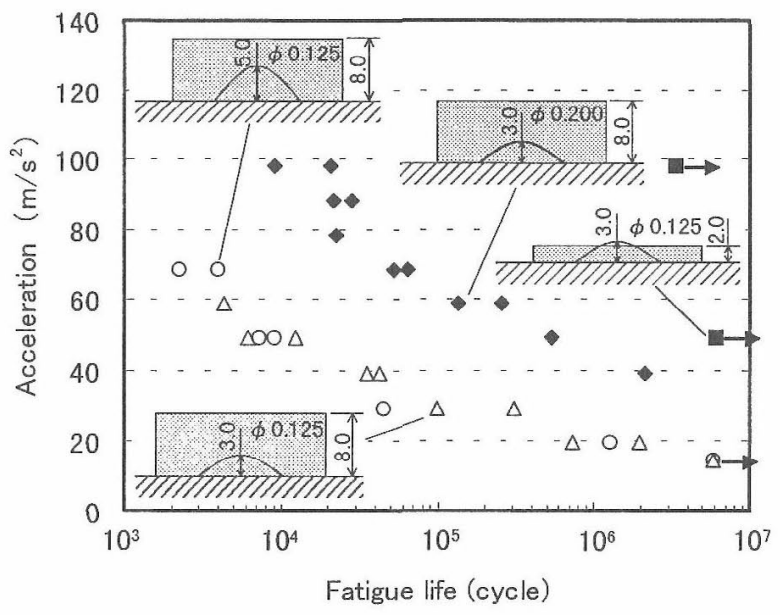

Fig. 2. Results of fatigue test for aluminum bonding wire protected with silicone gel under vibration.

（○）と試験片 $2(\triangle)$ の結果より，ループ高さはワイヤ の疲労寿命にあまり影響せず，また，試験片 $2(\triangle)$ と 試験片 3 ( の 試験結果を比べると, ワイヤ径は疲労 寿命に大きく影響することがわかる。さらに，試験片 2 $(\triangle)$ と試験片 $4($ 回) の結果から，ゲル厚さも疲労寿命 に大きく影響することがわかる。

\section{3 ゲル封止ワイヤの振動環境下疲労寿命予測}

\section{$3 \cdot 1$ ゲル封止ワイヤの振動解析}

前章の痩労試験の各試験片, 加振加速度においてワイ ヤに生じるひずみを求めるため, Fig. 1 の試験片のゲル とりイヤをFig. 3のようにモデル化し, 有限要素法でゲ ルとワイヤの振動解析を行った。ワイヤは 3 節点ビーム 要素, ゲルは 20 節点ソリッド要素でモデル化した。 ビー ム要素の節点と同一座標にあるソリッド要素の節点が振 動洔に同一変位となるように拘束条件を与兄，ゲルとり イヤの連成振動を模擬した。解析には沉用コードの

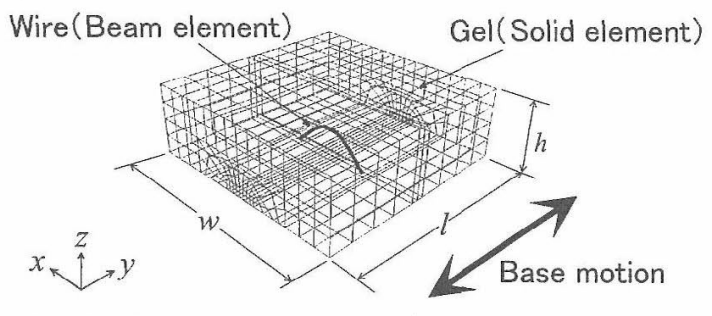

Fig. 3. Finite element model of aluminum bonding wire protected withsilicone gel.

ABAQUS莸用いた. ABAQUSでは粘弾性材料の複素弾 性率を材料データとして与光れば，粘弾性材料から成る 構造体の周波数応答が求められる。ワイヤは弾性材料， ゲルは粘弾性材料として材料定数を入力し, 加振周波数 $60 \mathrm{~Hz}$ でゲルの底面とワイヤのボンディング部が Fig. 3 の $y$ 方向に加振される条件でワイヤのひずみ在計算した。 著者らは，このような連成振動解析の計算結果とレーザ ドップラ振動計によるゲル封止ワイヤの周波数応答特性 の測定結果が良く一致することを確認している.

\section{$3 \cdot 2$ 疲労寿命予測}

前項の振動解析で Table I の各試験片, 加振加速度に おいてワイヤに生じるひず多を求め, Fig. 2の縦軸をり イヤのネック部のひずみ範团に変換した結果を Fig. 4 に 示す。振動解析ではワイヤのひずみの最大值はワイヤの ネック部で認められたが, 疲労試験においてもワイヤの 断線はネック部で生じた. Fig. 4 には, ウェッジボンデ イングしたワイヤ径 $300 \mu \mathrm{m}$ のアルミワイヤの一端に強制 変位を機戌的に与光た疲労試験 (以降, 強制変位瘦労試 験と略記する) で得た累積断線確萃 50\%の疲労寿命を Manson-Coffin 則でまとめた直線を併記した. Fig. 4 か ら, 縦軸をひずみ範囲に変換すれば，第 2 章の試験結果 は強制変位痏労試験の寿命曲線の近傍にプロットでき, ワイヤ径, ゲル厚さの買なる試験結果が一本の寿命曲線 に整理できることがわかる。

また, 別途行った加振周波数 $100 \mathrm{~Hz}$ での疲労試験の結 果も Fig. 4 に付記した。ゲルは粘弾性材料であるため,

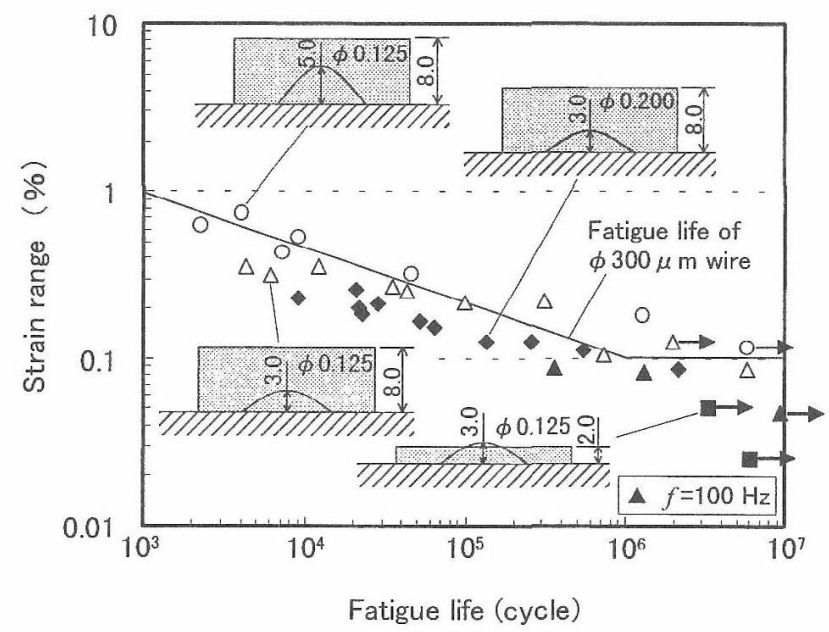

Fig. 4. Fatigue life of aluminum bonding wire protected with. silicone gel under vibration. 
ワイヤに生じるひず就加振周波数に大きく依存する。 ア・1 節の振動解析では, ゲルの粘弾性を考慮してワイヤ のひず多算出するため, 加振周波数 $100 \mathrm{~Hz}$ の試験結果 （A）も強制变位疲労試験の寿命曲線の近傍にプロット できた。これより，加振周波数に関わらず疲労試験の結 果は一本の寿命曲線に整理できることがわかる。

以上から，次のような手順でゲル封止されたワイヤの 累積断線確率 $50 \%$ の痏労寿命が予測できる。

（I）ゲル封止されたワイヤの解析モデルを作成する。

(II) ゲルとワイヤの連成振動解析を実施し, ワイヤ のネック部のひずみ範囲 $\Delta \varepsilon$ を求める。

(III) 強制変位疲労試験の寿命評価式

$$
N_{f}=\left(\Delta \varepsilon / \varepsilon_{0}\right)^{-1 / m}
$$

に (II) で求めたひず範网 $\Delta \varepsilon$ を代入して疲労寿命 $N_{f}$ を得る。ただし，Fig. 4のようにひずみ範囲 $0.1 \%$ を疲労 限と考え， $\Delta \varepsilon<0.1 \%$ では断線しないとする。

例えば，式 (1) 觉積断線確率 $0.1 \%$ の寿命評価式とす れば，上記の手順と同様の手順で累積断線確率 $0.1 \%$ の 疲労寿命が予測できる。

\section{4 ゲル封止ワイヤの簡易寿命評価法}

\section{1 設計対象}

自動車に搭載される電子部品では，Fig. 5 に示すよう にプリント基板上の配線やボンディングワイヤを水滴, 油滴などから保護するために，シリコーンゲルをハウジ ング内に充填しているものが多い。このような電子部品 のボンディングワイヤの振動に対する痏労寿命を簡易的 に評洒する于法を開発した。

簡易寿命俨洒法では，実際の電子部品をゲルとワイヤ のみに簡略化した Fig. 6 のひず多評価モデルに置き換え てワイヤのネック部のひず範囲を求め, それを式 (1)に

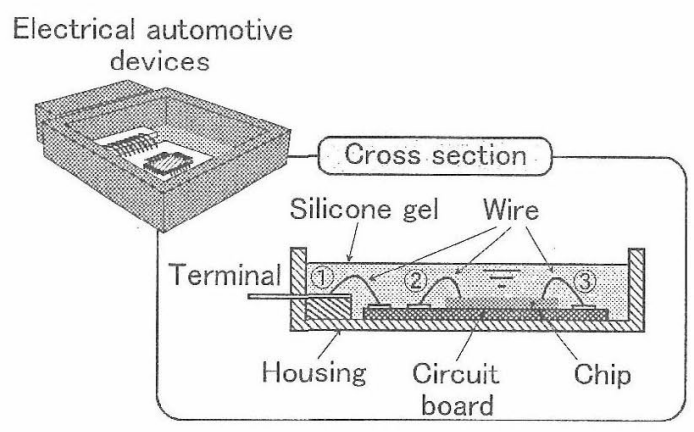

Fig. 5. Cross section of typical electrical automotive device.

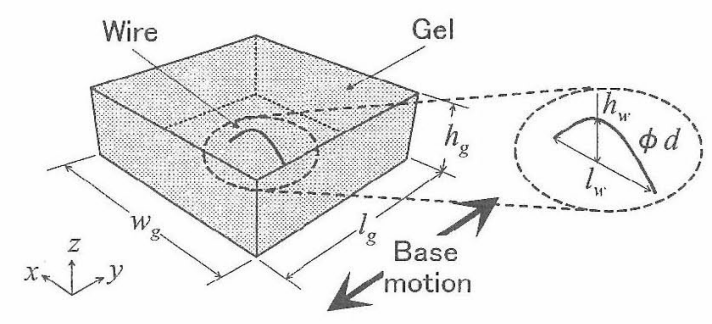

Fig. 6. Modeling of electrical device for calculation of strain range of wire.
代入してワイヤの瘦労寿命を簡易的に求める。ワイヤは 基板上の様々な䈏所にあるが, 振動によって最も疲労破 断しやすいのは，ゲルの振幅が最も大きくなる中央付近 のワイヤ（Fig. 5 では(2)）である。ハウジングの側壁近 くではゲルの振幅が小さいため，(1)，(3)のワイヤの疲労 破断は(2)よりも起こりにくい。したがって，簡易評価手 法では，ハウジング底面の中央にワイヤがあると仮定し てひずみを評価し，安全側の寿命評価を行う。また，加 振によるハウジングの変形は無視できるほど小さいので, 加振時にゲル側面は变形せず, 底面と同じ変位で振動す ると考える，加振方向岵ワイヤの疲労寿命に大きく影響 する。ワイヤが疲学破断するのは，Fig. 6のようにワイ ヤの張ってある方向と垂直 $(y$ 方向) に電子部品が加振 された場合である。したがって，ひずみ評洒モデルでは， ワイヤの張ってある方向は加振方向に対して完全に垂直 とする。

\section{$4 \cdot 2$ 簡易寿命評価法の流れ}

ゲル封止ワイヤの振動による痩労に対する簡易寿命評 価法の流れを Fig. 7 に示す。本手法では，まず設計対象 の電子部品をFig. 6のようなひずみ評価モデルに置き換 え, ワイヤ径 $d$, ループ高さ $h_{w}$, スパン長さ $l_{w}$, ゲルの $W_{g}$ 幅, ゲルの長さ $l_{g}$, ゲルの厭さ, 扎よび加振周波数 $f$ を設定する。次に，予め用意したひずみ範囲 $\Delta \varepsilon$ を求め 当近似式

$$
\Delta \varepsilon=F\left(d, h_{w}, l_{w}, w_{g}, l_{g}, h_{g}, f\right)
$$

にゲルすよびワイヤの寸法, 加振周波数の各值を人力し， 加振师速度 $9.8 \mathrm{~m} / \mathrm{s}^{2}$ でのワイヤのひずみ範囲圭概算する。 任意の加振加速度に対するひず夕範囲は，加振加速度と

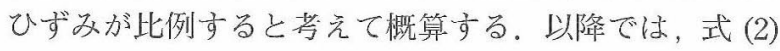
の近似式をひず文応答曲面と呼ぶ。続いて，ひずみ範四 の概算值を式 (1)の寿命評洒式に代入し, 振動環境下で のゲル封止ワイヤの疲労寿命を簡易的に求める。このよ うな簡易寿命評価法により，設計者はゲル，ワイヤの寸 法変更による瘦労寿命の変化を容易に確認でき, 基本構 造設計段階での試行錯誤が簡便に行える。

\section{$4 \cdot 3$ ひずみ応答曲面の作成}

本手法では，ゲルとワイヤの寸法，扣よび加振周波数 を入力，ワイヤのひずみ範国走出力とする式 (2)のひず み応答曲面を作成する。ひずみ応答曲面を作成するため

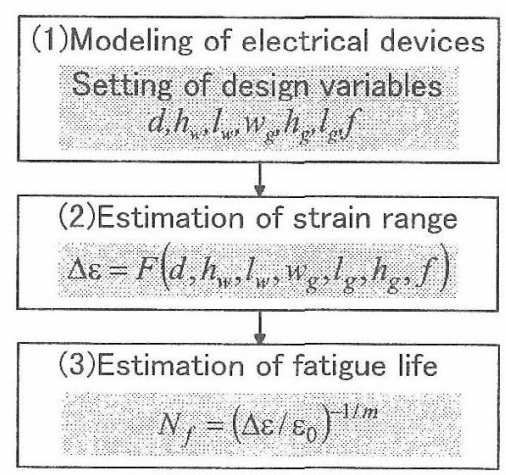

Fig. 7. Estimation flow. 
に, 近似式に含まれる未知係数を求める。この未知係数 は, ゲルとワイヤの寸法, および加振周波数の異なるゲ ル封止ワイヤの連成振動解析を数回実施し，その数回の 計算結果を利用して決定する。以降では，未知係数の決 定に利用する計算結果を教師データと呼ぶ.

$4 \cdot 3 \cdot 1$ 直交表による教師データの選択 信頼度の 高い応答曲面を作成するためには，設計空間上に適切 に分散された教師データで未知係数を決定する必要があ る. そこてで, 加振周波数 $f$ を除く 6 変数（ワイヤ径 $d$, ル 一プ高さ $h_{w}$, スパン長さ $l_{w}$, ゲルの幅 $w_{g}$, ゲルの長さ $l_{g}$, ゲルの厚さ $h_{g}$ ) を 3 水準系の L27 直交表 ${ }^{4)}$ に割り付 け，27 組の各組み合せに対応した連成振動解析を実施し た. 加振周波数を除く 6 変数の水準範囲を Table IIに示 す. 加振周波数については, 直交表には割り付けず, 27 組の各解析において $10 \sim 100 \mathrm{~Hz}$ 間の 10 点 $\{10.0$, $12.9,16.7,21.5,27.8,35.9,46.4,59.9,77.4,100.0\}$ でワイヤのひずみを計算した．結局， $27 \times 10=270$ 組の 計算結果を教師データとした。

$4 \cdot 3 \cdot 2$ 応答曲面の作成方法 ゲル, ワイヤの寸法, 加振周波数とワイヤのひずみの間には強い非線形性が存 在する。また，本研究で選んだ設計変数では，複数の設 計変数間に複雑な交互作用があるので, 応答曲面として Chebyshev の直交関数 ${ }^{4)}$ は使い難い. そこで, 本評価法 ではひずみ応答曲面として非線形性の強い入出力関係の 写像に有効なニューラルネットワーク（以降 NN と略記 する）を採用する. NN の構造を Fig. 8 に示す. 入力層 の素子数は 7 個の設計変数と近似式の定数項に相当する バイアス項 1 の合計 8 である. 中間層の素子数は 40 と し，出力層の素子数はひずみ範囲の 1 である. NN では 未知係数 $\boldsymbol{w}$ を決定することを $\mathrm{NN}$ の学習と呼ぶ. NN は 未知係数の数が非常に多いため, 学習を誤れば Fig. 9 (b) のように, 教師データ $(\times)$ の近似精度は良いが，教師デ

Table II . Level values.

\begin{tabular}{c|c|c|c}
\hline Factor & Level 1 & Level 2 & Level 3 \\
\hline Diameter of wire $d(\mathrm{~mm})$ & 0.100 & 0.200 & 0.300 \\
\hline Height of wire $h_{w}(\mathrm{~mm})$ & 1.0 & 2.0 & 3.0 \\
\hline Length of wire $l_{w}(\mathrm{~mm})$ & 7.0 & 11.0 & 15.0 \\
\hline Length of gel $w_{g}(\mathrm{~mm})$ & 20 & 50 & 80 \\
\hline Width of gel $l_{g}(\mathrm{~mm})$ & 20 & 50 & 80 \\
\hline Height of gel $h_{g}(\mathrm{~mm})$ & 1.2 & 3.2 & 5.2 \\
\hline
\end{tabular}

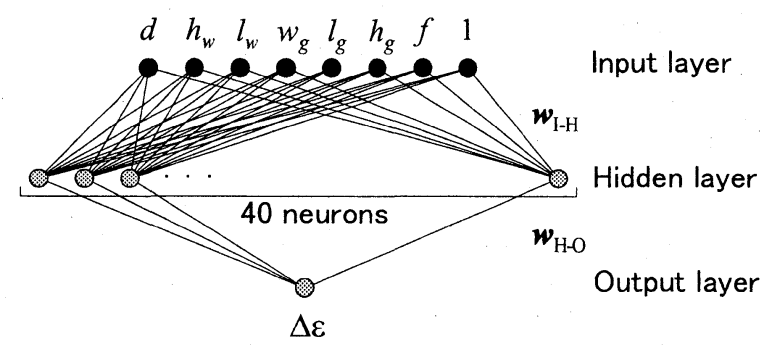

Fig. 8. Architecture of neural network.

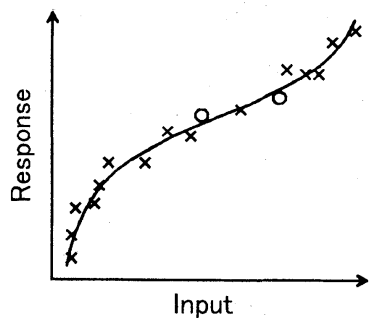

(a)A good fit to noisy data

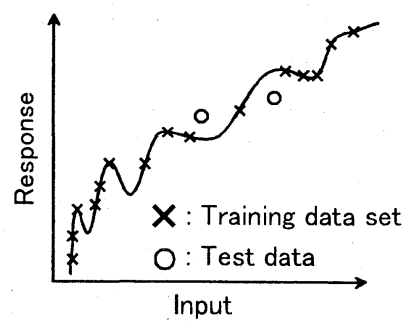

(b)Overfitting
Fig. 9. Generalization ability.

一タ以外の入力 $(\bigcirc)$ に対しては近似精度の悪い応答曲 面となる. 教師データ以外の入力に対しても近似精度の 良い, すなわち補間性能の良い Fig. 9 (a) のような応答 曲面を作成するために，ベイズ統計学に基づく適切化 ${ }^{5)}$ ７）適用する。補間性能の良い応答曲面は Fig. 9 (b) のような凹凸の激しい曲面では無く，Fig. 9 (a) のよう に滑らかな応答曲面である。そこで, ベイズ統計学に基 づく適切化を利用して「応答曲面は滑らかである」とい う情報を NN の学習に反映させ, 補間性能の良い応答曲 面を作成する。教師データを $\boldsymbol{x}$ としたとき, ベイズ統計 学に基づく NNの未知係数 $\boldsymbol{w}$ の決定 (学習) 手順は以 下の通りである.

（I） NN を確率的に解釈し，NN を尤度 $l(\boldsymbol{w} \mid \boldsymbol{x})$ とし て表現する.

（II）未知係数 $\boldsymbol{w}$ につての既知情報を事前密度 $p(\boldsymbol{w})$ の形に表現する.

（III） ベイズの定理により，事後密度 $p(\boldsymbol{w} \mid \boldsymbol{x})$ を求める.

$$
p(\boldsymbol{w} \mid \boldsymbol{x}) \propto l(\boldsymbol{w} \mid \boldsymbol{x}) p(\boldsymbol{w})
$$

(IV) 未知係数 $\boldsymbol{w}$ を決定する.

具体的には, $\mathrm{NN}$ は多変量正規分布の確率密度関数

$$
p(D \mid \boldsymbol{w}, \beta, A)=Z_{\mathrm{D}}(\beta)^{-1} \exp \left[-\beta E_{\mathrm{D}}(D \mid \boldsymbol{w}, A)\right]
$$

に従ってデータを発生すると考え, 式 (4)を NNの尤度 とする．ここで, $D$ は教師データの集合, $A$ はN の構 造, $\beta$ はひずみの計算值に含まれる誤差の尺度を表わし， $Z_{\mathrm{D}}(\beta)^{-1}$ は式 (3)の左辺を右辺と等しくするための規準化 定数である. $E_{\mathrm{D}}(D \mid \boldsymbol{w}, A)$ は教師データ $D=\left\{\boldsymbol{x}^{\mu}, \varepsilon^{\mu}\right\}$ が $\mathrm{NN}$ に与えられた場合の NN の出力 $F\left(\boldsymbol{x}^{\mu} ; \boldsymbol{w}, A\right)$ と $\boldsymbol{x}^{\mu}$ に 対する真の出力 $\varepsilon^{\mu}$ の 2 乗誤差

$$
E_{D}(D \mid \boldsymbol{w}, A)=\sum_{\mu} \frac{1}{2}\left[F\left(\boldsymbol{x}^{\mu} ; \boldsymbol{w}, A\right)-\varepsilon^{\mu}\right]^{2}
$$

である。添え字 $\mu$ は $\mu$ 組目の教師データを意味する。 「応答曲面は滑らかである」という既知情報を確率密度関 数で表現すると

$$
p(\boldsymbol{w} \mid \alpha, A, R)=Z_{\mathrm{w}}(\alpha)^{-1} \exp \left[-\alpha E_{\mathrm{w}}(\boldsymbol{w} \mid A, R)\right]
$$

となる.ここで, $R$ は未知係数の事前分布, $\alpha$ は $\boldsymbol{w}$ の事 前密度の特性を決定する係数, $Z_{\mathrm{w}}(\alpha)$ は規準化定数, $E_{\mathrm{W}}(\boldsymbol{w} \mid A, R)$ は

$$
E_{\mathrm{w}}(\boldsymbol{w} \mid A, R)=\sum_{i} \frac{1}{2} w_{i}^{2}
$$

である. 式 (3)に式 (4)の尤度と式 (6)の事前密度を代 入し，

$$
p(\boldsymbol{w} \mid D, \alpha, \beta, A, R)=Z_{\mathrm{M}}(\alpha, \beta)^{-1} \exp \left(-\alpha E_{\mathrm{w}}-\beta E_{\mathrm{D}}\right)
$$


となる. $Z_{\mathrm{M}}(\alpha, \beta)^{-1}$ は規準化定数である. $\mathrm{NN}$ の学習と は, 事後密度を最大とする未知係数 $\boldsymbol{w}$ を見つけることに 相当する.したがって, ベイズ統計学に基づく適切化を 利用した NNの学習では, 誤差関数

$$
M=\alpha E_{\mathrm{w}}+\beta E_{\mathrm{D}}
$$

を最小化する $\boldsymbol{w}$ を見つける，ただし，すべての未知係数 に対して同一の事前分布を仮定するのは不自然 ${ }^{6}$ なため, 入力層一中間層間の未知係数 $\boldsymbol{w}_{\mathrm{I}-\mathrm{H}}$ と中間層一出力層間 の未知係数 $\boldsymbol{w}_{\mathrm{H}-\mathrm{O}}$ に対して異なる事前分布を仮定する。 また，バイアス項に乗じられる未知係数に事前分布は仮 定しない.したがって, 式 (9)の誤差関数は

$$
M=\sum_{c} \alpha_{c} E_{\mathrm{w}}^{c}+\beta E_{\mathrm{D}}
$$

となる。ここで， $c$ は異なる事前分布を意味する。未知 係数 $\boldsymbol{w}$ の決定には逆誤差伝ぱ則 ${ }^{8)}$ を用いた。

式 (10)の $\alpha_{c}, \beta$ はべイズ統計学に基づくモデル選択基 準を利用して次のように決定する. $\alpha_{c}, \beta$ の事後密度は

$$
p\left(\alpha_{\mathrm{c}}, \beta \mid D, A, R\right)=\frac{p\left(D \mid \alpha_{c}, \beta, A, R\right) p\left(\alpha_{\mathrm{c}}, \beta\right)}{p(D \mid A, R)}
$$

となる．ここで， $\alpha_{c} ， \beta$ の事前分布を無情報事前分布 ${ }^{9)}$ とすると, $\alpha_{c}, \beta$ の事後密度は式 (11)の右辺の $p\left(D \mid \alpha_{c}, \beta\right.$, $A, R)$ にのみ依存する. $p\left(D \mid \alpha_{c}, \beta, A, R\right)$ は

$$
p\left(D \mid \alpha_{\mathrm{c}}, \beta, A, R\right)=\frac{Z_{\mathrm{M}}\left(\alpha_{\mathrm{c}}, \beta\right)}{Z_{\mathrm{w}}\left(\alpha_{\mathrm{c}}\right) Z_{\mathrm{D}}(\beta)}
$$

と書ける. 式 (12)の対数の $\alpha_{c}, \beta$ に関する偏微分を 0 と おくと，式 (12)を最大とする $\alpha_{c}, \beta$ は

$$
\alpha_{c}=\gamma / 2 E_{\mathrm{w}}^{c}, \beta=(N-\gamma) / 2 E_{\mathrm{D}}
$$

となる. $N$ は教師データと出力層の素子数の積であり， $\gamma$ は未知係数の有効数と呼ばれ, 0 から $k$ までの值をとる. $k$ は末知係数の個数である. 有効数 $\gamma$ の計算は複雑なた め, 本研究では簡易的に $\gamma=k / 2$ とした.

$4 \cdot 3 \cdot 3$ 補間性能と近似精度 前項の手順で作成し たひずみ応答曲面の補間性能を調査した，加振周波数に 関する補間性能を調査するため, L27 直交表の No. 1， No. 3 と No. 27 の設計変数の組み合せに対して, ワイヤ のひずみ範囲を応答曲面で概算した. No. 1, No. 3 と No. 27 の設計変数の組み合せを Table III に示す. No. 15, No. 23 およびNo. 25 の設計変数の組み合せについ ても後に調査対象とするため, Table III に付記した. ワイ ヤのひずみはNo. 3 の組み合せで最小となり, No. 27 の 組み合せで最大となる. Fig. 10 にワイヤのひずみ範囲の

Table III. Design variables for training data.

\begin{tabular}{l|c|c|c|c|c|c}
\hline & $\begin{array}{c}d \\
(\mathrm{~mm})\end{array}$ & $\begin{array}{c}h_{w} \\
(\mathrm{~mm})\end{array}$ & $\begin{array}{c}l_{w} \\
(\mathrm{~mm})\end{array}$ & $\begin{array}{c}w_{g} \\
(\mathrm{~mm})\end{array}$ & $\begin{array}{c}l_{g} \\
(\mathrm{~mm})\end{array}$ & $\begin{array}{c}h_{g} \\
(\mathrm{~mm})\end{array}$ \\
\hline No.1 & 0.1 & 1.0 & 7.0 & 20 & 20 & 1.2 \\
\hline No.3 & 0.3 & 3.0 & 15.0 & 20 & 80 & 1.2 \\
\hline No.15 & 0.2 & 3.0 & 15.0 & 50 & 80 & 3.2 \\
\hline No.23 & 0.2 & 3.0 & 7.0 & 50 & 50 & 5.2 \\
\hline No.25 & 0.2 & 1.0 & 7.0 & 80 & 20 & 5.2 \\
\hline No.27 & 0.1 & 3.0 & 15.0 & 80 & 80 & 5.2 \\
\hline
\end{tabular}

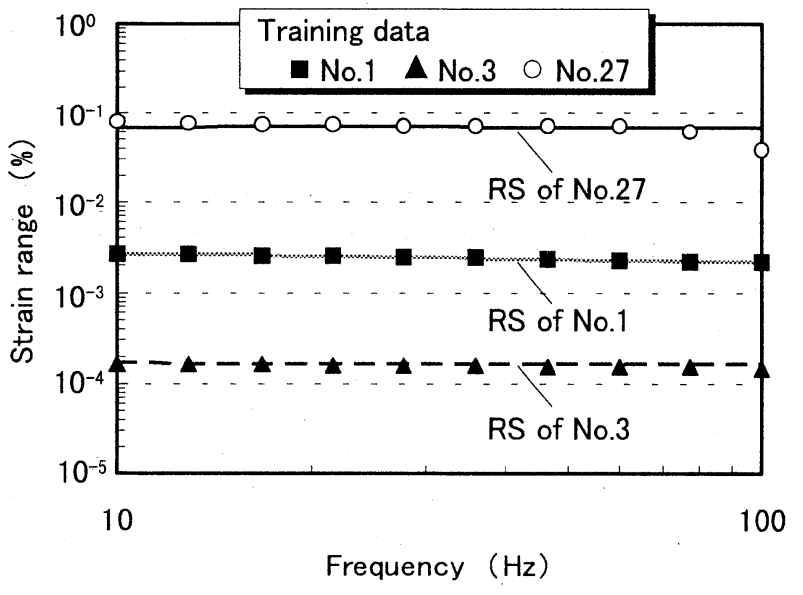

Fig. 10. Generalization ability for frequency.

計算值（教師データ）と応答曲面によるひずみ範囲の概 算值を示す。困中の RS は応答曲面 (Response surface) の略である。非常に滑らかな応答曲面が Fig. 10 で認め られることから, 加振周波数に対して補間性能の良い応 答曲面が前項の手順で作成できることが確認できた。

次に，ゲルやワイヤ寸法に関する補間性能を調査した. 特に, ワイヤ径 $d$ およびゲル厚さ $h_{g}$ とワイヤのひずみの 間には強い非線性が存在するため, 適切な補間が難しい. Table III に示した L27 直交表の No. 1 と No. 23 の設計 変数の組み合わせに対し, ワイヤ径のみを $100 \mu \mathrm{m}$ から $300 \mu \mathrm{m}$ まで変化させ, 加振周波数 $10 \mathrm{~Hz}$ のワイヤのひず み範囲をひずみ応答曲面で概算した．また，この概算值 の近似精度を確認するため, ゲルとワイヤの連成振動解 析でワイヤのひずみ範囲を計算した．No. 1 の場合，ワ イヤ径 $100 \mu \mathrm{m}$ の計算結果は教師データなので, $150 \mu \mathrm{m}$ から $300 \mu \mathrm{m}$ まで $50 \mu \mathrm{m}$ 間隔でワイヤ径を増加させてひず みを計算した。No. 23 に対しても，教師データの $200 \mu \mathrm{m}$ を除く $50 \mu \mathrm{m}$ 毎のワイヤ径でひずみを計算した。 Fig. 11 に，応答曲面によるひずみ範囲の概算值と有限 要素法によるひずみ範囲の計算值を示す。ひずみの応答 曲面は非常に滑らかであり，ワイヤ径に関して補間性能 の良い応答曲面が生成できた。ただし，応答曲面による

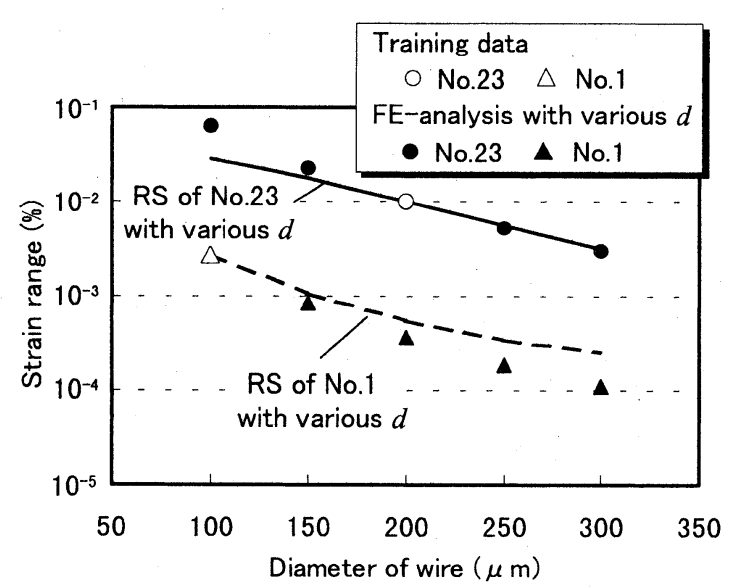

Fig. 11. Generalization ability for diameter of wire. 
ひずみ範囲の概算值は教師データ（Fig. 11 のと $\triangle)$ とは良く一致しているが，教師データ以外の計算值 （Fig. 11ののとム）と比較すると, 誤差の最も大きい点 で概算值は計算值の $1 / 2$ となった。このことは，ワイヤ 径とワイヤのひずみの間には強い非線形性があり，ひず みの近似が難しいことを示唆している。

ゲル厚さに関する補間性能を調査した，L27 直交表の No. 15 と No. 25 の設計変数の組み合わせに対して, ゲ ル厚さのみを $1.2 \mathrm{~mm}$ から $5.2 \mathrm{~mm}$ まで変化させ, 加振周 波数 $10 \mathrm{~Hz}$ のワイヤのひずみ範囲をひずみ応答曲面で概 算した。 この概算值の近似精度を確認するため，ゲル厚 さ $1.2 \mathrm{~mm}, 3.2 \mathrm{~mm}$ と $5.2 \mathrm{~mm}$ の場合のひずみ範囲を有限 要素法で計算した. No. 15 のゲル厚さ $3.2 \mathrm{~mm}$, No. 25 の ゲル厚さ $5.2 \mathrm{~mm}$ の計算結果は教師データである. Fig. 12 に，応答曲面によるひずみ範囲の概算值と有限要素法に よるひずみ範囲の計算值を，横軸をゲルの厚さとして示 す、ひずみ応答曲面は非常に滑らかであることから，ゲ ルの厚さに対して補間性能の良い応答曲面が生成できた と考えられる。ただ，ワイヤ径の場合と同様に，応答 曲面によるひずみの概算值は教師データ（Fig. 12 の と〉）とは非常に良く一致しているが，教師データ以外 の計算值（Fig. 12のロとつ）と比較すると, 最も誤差 の大きいNo. 15 でゲル厚さ $5.2 \mathrm{~mm}$ に扔いて概算值は計 算值の 1.5 倍となった。

本評価法は補間性能の良い応答曲面が作成できるた め, 設計者の基本構造設計時に有用なツールとして活用 できる，ただし，ひずみとゲル，ワイヤの寸法および加 振周波数は強い非線形性が存在するため, 条件によって はひずみ範囲の概算值と有限要素法による計算值に差異 が認めらた。このような場合, 式 (1)にひずみ範囲の概

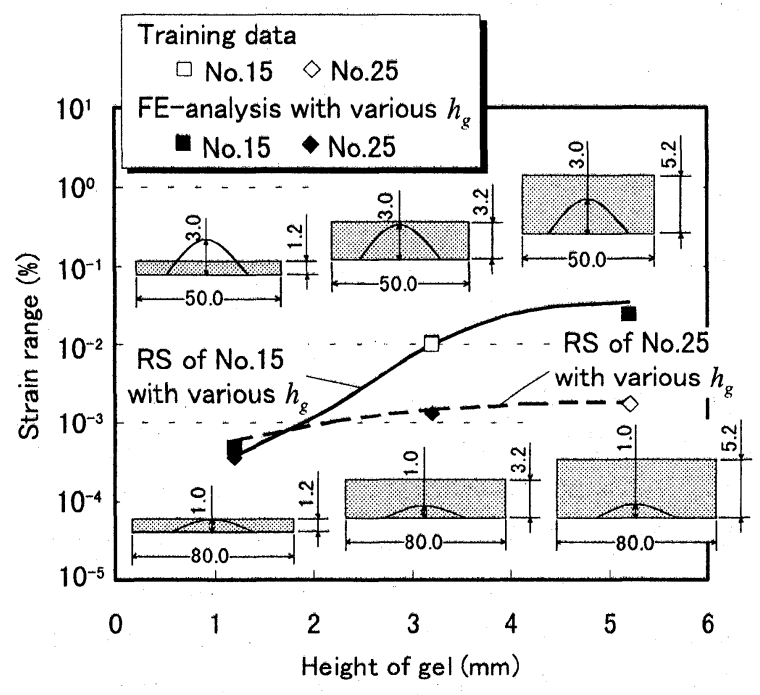

Fig. 12. Generalization ability for Height of gel.
算值を代入して求めた疲労寿命は実際の疲労寿命と大き く異なる可能性がある。したがって, 提案する簡易評価 法は基本構造設計時に活用し, 最終的な構造を決定する 段階では $3 \cdot 2$ 節の寿命予測法でワイヤの疲労寿命を確 認すべきと考える.

\section{5 結 言}

本研究ではゲル封止されたワイヤの振動環境下の疲労 強度を明らかにするため, ゲル封止ワイヤの疲労寿命予 測法と簡易寿命評価法を提案し，以下の結論を得た.

(1) ゲル封止されたワイヤの振動環境下の疲労試験を 実施し, ワイヤ径とゲルの厚さはワイヤの破断寿命に大 きく影響することがわかった。

(2) 上記疲労試験の各条件に対応するゲルとワイヤの 連成振動解析を実施し, 縦軸をワイヤのひずみ範囲横軸 を破断繰返し数として試験結果を整理したところ, 試験 結果は一本の寿命曲線にまとめられた。

(3) ゲルとワイヤの連成振動解析で計算したワイヤの ひずみ範囲とワイヤ単体の強制変位疲労試験で求めた寿 命評価式からワイヤの疲労寿命を予測する手法を提案し た.

（4）ゲルとワイヤの寸法変更による疲労寿命の変化を 簡便に概算できる応答曲面を利用したゲル封止ワイヤの 簡易寿命評価法を提案した。

(5) ベイズ統計学に基づく適切化を利用して応答曲面 を作成し, ゲル, ワイヤの寸法および加振周波数に対し て優れた補間性能を有する応答曲面を得た。これより， 簡易寿命評価法は設計者の基本構造設計時に有用なツー ルであることがわかった.

\section{参 考 文 献}

1) 竹田憲生, 成瀬友博, 服部敏雄, 浅野雅彦; 日本材料学 会第 49 期通常総会・学術講演会, 57 (2000).

2) 竹田憲生, 成瀬友博, 服部敏雄, 大野啓充, 材料, 50 , 1305(2001).

$3)$ R. T. Haftka and E. P. Scott, "Theoretical and Applied Mechanics 1996", edited by T. Tatsumi, E. Watanabe and T. Kambe, P.103 (1997) Elsevier Science B. V..

4 ) 田口玄一, “第 3 版実験計画法”, p.144 (1977) 丸善.

5 ) D. J. C. Mackay, Neural Computation, 4, 415 (1992).

6) D. J. C. Mackay, Neural Computation, 4, 448 (1992).

7) P. M. Williams, Neural Computation, 7, 117 (1995).

8) J. Hertz, A. Krough and R. G. Palmer, "INTRODUCTION TO THE THEORY OF NEURAL COMPUTATION”, p.115 (1991) Addison-Wesley.

9 ）繁柝算男, “ベイズ統計学入門”, p.53 (1985) 東京大学出 版会. 